\title{
Food in rural northern Norway in relation to Sami ethnicity: the SAMINOR 2 Clinical Survey
}

\author{
Natalia Petrenya ${ }^{1, *}$, Guri Skeie ${ }^{1}$, Marita Melhus ${ }^{2}$ and Magritt Brustad ${ }^{1}$ \\ 'Department of Community Medicine, Faculty of Health Sciences, UiT The Arctic University of Norway, Postboks \\ 6050 Langnes 9037, Tromsø, Norway: ${ }^{2}$ Centre for Sami Health Research, Department of Community Medicine, \\ UiT The Arctic University of Norway, Tromsø, Norway
}

Submitted 2 January 2018: Final revision received 25 March 2018: Accepted 24 April 2018: First published online 29 May 2018

\begin{abstract}
Objective: To estimate current food intake in the population of northern Norway and to investigate the impact of self-perceived Sami ethnicity and region of residence on food intake.

Design: The data are part of the second cross-sectional survey of the Populationbased Study on Health and Living Conditions in Regions with Sami and Norwegian Populations (the SAMINOR 2 Clinical Survey, 2012-2014). Food intake was assessed by an FFQ. Ethnic and regional differences in food intake were studied by sex-specific, multivariable-adjusted quantile regression models.

Setting: Ten municipalities (rural northern Norway).

Subjects: Males ( $n$ 2054) and females ( $n$ 2450) aged 40-69 years (2743 non-Sami, 622 multi-ethnic Sami, 1139 Sami).

Results: The diet of Sami participants contained more reindeer meat, moose meat, food made with animal blood and freshwater fish; and contained less lean fish and vegetables. In the inland region, the consumption of reindeer meat was greatest in Sami participants, followed by multi-ethnic Sami participants and non-Sami participants, who had the lowest consumption (median 25, 12 and $8 \mathrm{~g} / \mathrm{d}$, respectively). Compared with the inland region, fish roe/liver intake was higher in the coastal region and lean fish intake was twice as high (41 and $32 \mathrm{~g} / \mathrm{d}$ in males and females, respectively).

Conclusions: When compared with non-Sami participants, those with solely selfperceived Sami ethnicity reported a significantly different intake of several foods, especially reindeer meat in the inland region. Multi-ethnic Sami tended to have similar diets to non-Sami. Residence in the coastal region predicted higher fish and roe/liver intake.
\end{abstract}

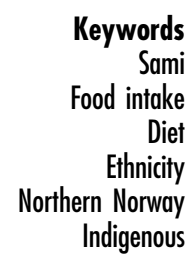

Many traditional foods in the North (e.g. reindeer meat and fish) have long been recognized to be rich in nutrients and are thus favourable for health ${ }^{(1,2)}$. Indeed, traditional local food systems are strongly related to health and well-being in Indigenous Peoples ${ }^{(3,4)}$. Lifestyle behaviours such as cigarette smoking, lack of physical activity, excessive alcohol intake and dietary changes like reduced intake of traditional local foods and increased intake of processed foods appear to contribute to rapidly growing obesity rates and incidences of CVD, type 2 diabetes, lung and colorectal cancers in certain Indigenous populations in the $\operatorname{Arctic}^{(5-8)}$.

The Sami are an Indigenous People in Norway and represent an ethnic minority in the country ${ }^{(9)}$. Although the majority of the Sami population can be found in Norway, they also live in Sweden, Finland and Russia.
Historically, the largest part of the Sami population in Norway has resided north of the Arctic Circle, with a smaller population in mid-Norway. In 1970, the number of Sami living in Norway was estimated at about 40000 individuals, but there is no current official statistic on this number and it could vary according to the definition of 'Sami' applied ${ }^{(10)}$.

In the past, and similarly to other Indigenous inhabitants of the circumpolar geographical area, the Sami economy was based on herding and breeding reindeer, fishing, hunting, gathering and some agriculture ${ }^{(11)}$. Therefore, primary traditional foods included reindeer (all parts, including meat, blood and organs) and fish, especially oily fish. In coastal communities, fish liver/roe with fresh fishliver oil were traditionally consumed. A variety of harvested foods (wild fowl and mammals, plants and berries) 
have also been important components of the Sami diet, and crucial determinants of the Sami diet included region of residence (coastal $v$. inland (mountain) regions), availability of foods in their natural harvest seasons, ability to purchase foods (e.g. flour, butter/margarine and sugar) and involvement in farming and agriculture ${ }^{(12-15)}$. Dairy products, cereals, fruit and vegetables were consumed in small amounts, whereas high consumption of boiled, unfiltered coffee has long been recognized as an important component of the Sami culture and diet ${ }^{(16,17)}$.

Existing studies on the diet of the Sami population in Norway were published between the $1960 \mathrm{~s}^{(12)}$ and the $2000 s^{(17,18)}$. However, these studies were based on small sample sizes and focused mainly on reindeer herders from inland Finnmark County ${ }^{(17,18)}$. Limited dietary data were collected in the first survey of the Population-based Study on Health and Living Conditions in Regions with Sami and Norwegian Populations (the SAMINOR 1 Survey, 2003$2004)^{(19-21)}$ and these data have been used to identify dietary patterns in relation to Sami ethnicity ${ }^{(20)}$, including dietary patterns in childhood $^{(21)}$. An interesting finding was that the differences in dietary patterns were stronger by geographical region than by Sami/Norwegian ethnicity. A childhood diet high in fish was associated with residence in a coastal region, whereas a childhood diet high in reindeer meat and other parts of the reindeer was more common in the inland regions ${ }^{(21)}$. It was also observed that the associations between ethnicity and dietary patterns were more prominent in inhabitants of the inland than the coastal region ${ }^{(21)}$.

Interesting, relevant, population-based data from Sweden regarding incidence of and mortality from CVD and cancer in relation to aspects of the Sami diet and lifestyle have shown that: (i) oily fish was a very important dietary component for the reindeer-herding Sami of southern Lapland in the 1930s to $1950 \mathrm{~s}$, and it is still consumed more frequently among people of Sami ethnicity; (ii) historical Sami and present-day reindeer-herding Sami populations have higher intakes of fat, blood and boiled coffee, and lower intakes of cultivated vegetables, bread and fibre, than present-day non-Sami populations; (iii) there was no clear evidence that the studied aspects of the 'traditional Sami' diet have beneficial effects on health outcomes in the general northern Swedish population; and (iv) more detailed, updated information on dietary intake and lifestyle among the Sami population is required ${ }^{(22-26)}$. Therefore, we aimed to estimate current food intake in the Sami compared with the non-Sami population of selected municipalities within northern Norway and to investigate the impact of self-perceived Sami ethnicity and region of residence on food intake.

\section{Methods}

\section{Study design and population}

The SAMINOR 2 Clinical Survey is a cross-sectional study conducted by the Centre for Sami Health Research, UiT The Arctic University of Norway in 2012-2014. Data collection for the SAMINOR 2 Clinical Survey was carried out in ten municipalities (Fig. 1). All inhabitants aged 40-79 years and residing in these municipalities were invited to participate in the study by personal letter. Our sample considers only the 10399 invitees aged 40-69 years, of

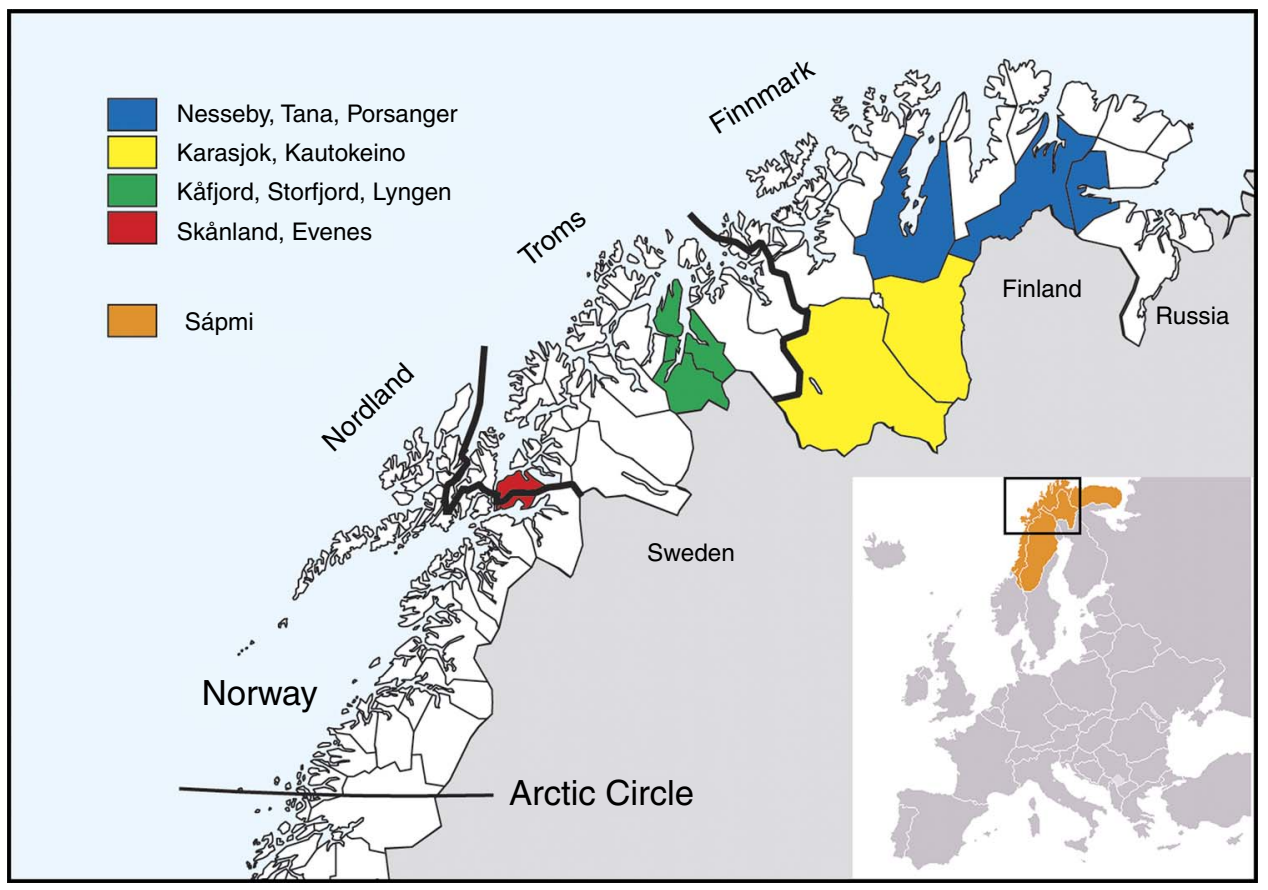

Fig. 1 Map of study sites 
whom 4876 attended the survey (participation rate $47 \%$ ). In this age group, data were collected through an eightpage self-administered questionnaire, which contained a four-page FFQ (see www.saminor.no for an English translation of the questionnaire), a short clinical examination and analyses of blood samples.

We excluded participants who did not provide information on ethnicity ( $n$ 115), as well as immigrants from non-Western European, Asian and African countries ( $n$ 69), because the questionnaire may not cover their diet. We further excluded twenty-nine males and sixty-two females because of incomplete FFQ responses ( $>50 \%$ blanks on standardized food frequency intake per week ( $\geq 57$ food items)); two males and five females with missing height and weight measurements; and forty males and fifty females within the top and bottom $1 \%$ of the ratio of energy intake (EI) to BMR (EI:BMR) ${ }^{(27)}$. Totally, 372 participants were excluded (7.6\%), resulting in a final analytical sample of 4504 individuals (2054 males and 2450 females).

\section{Questionnaire data}

Ethnicity was based on self-reported information from the SAMINOR 2 Clinical Survey questionnaire, which included the question: 'What do you consider yourself to be?' Response options were 'Norwegian', 'Sami', 'Kven' and 'Other (please describe)'. Participants who chose solely 'Other' ( $n$ 142) were further divided into: immigrants from Western European countries and immigrants from nonWestern European, Asian and African countries. Ethnicity was then categorized as: (i) non-Sami, including participants who considered themselves as something other than Sami (i.e. Norwegian, Kven or immigrant from Western European countries, $n$ 2856); (ii) multi-ethnic Sami, including participants who defined themselves as Sami in combination with any kind of other ethnic background ( $n$ 643); and (iii) Sami, which included participants who defined themselves as Sami only ( $n$ 1193).

The SAMINOR 2 Clinical Survey FFQ was a slightly modified version of the FFQ from the Norwegian Women and Cancer (NOWAC) Study ${ }^{(28,29)}$, which has previously been validated for the general female population of Norway ${ }^{(29-31)}$. Thus the FFQ covered a wide range of food items commonly consumed in Norway, as well as known traditional food items. Participants reported the frequency with which listed foods and beverages were consumed over the past 12 months. Information on the usual amount consumed was also collected for some food items. We used the NOWAC Study nutrient calculation program to estimate the amounts eaten. Herein we provide consumption information for the following twenty-three broad food groups and individual food items $(\mathrm{g} / \mathrm{d})$ : vegetables, fruit/berries, potatoes, dairy products, total fish, lean fish, oily fish, fish products, red meat (pork, beef and mutton)/ meat products, sauces, chicken, cereal products, breads/ crispbreads, fat as spread on bread, total coffee, baked goods, salty snacks, sweets, freshwater fish (e.g. perch, grayling, pike, arctic char, common whitefish, trout), fish roe/liver, reindeer meat, moose meat and food made with animal blood. Two traditional foods, seagull eggs and tundra grouse (ptarmigan; Lagopus spp.), were rarely consumed and thus were not included in the analysis. The food items included in the broad food groups are shown in the online supplementary material, Table S1.

Data on education, physical activity and smoking status were taken from questionnaires. Education was categorized as $<13$ years and $\geq 13$ years; physical activity was reported on a scale from 1 (very low) to 10 (very high) and categorized as low (1-3), moderate (4-7) or high (8-10); and smoking status was categorized as current, former or never.

\section{Clinical examination}

Height and weight were measured using an electronic Height, Weight \& Fatness Measuring System device (DS-103; Dongsahn Jenix, Seoul, South Korea), with the participants wearing light clothing and no shoes. Height was measured to the nearest $0 \cdot 1 \mathrm{~cm}$ and weight to the nearest $100 \mathrm{~g}$. BMI was then calculated and categorized into two groups: normal/overweight $\left(<30 \mathrm{~kg} / \mathrm{m}^{2}\right)$ and obese $\left(\geq 30 \mathrm{~kg} / \mathrm{m}^{2}\right)$.

\section{Register-based variables}

Sex, year of birth and municipality of residence were obtained from the National Registry (Folkeregisteret). Age was defined as that of participants at the end of the year in which clinical examination took place, and was categorized into 40-49, 50-59 and 60-69 years. Geographical region of residence was categorized as the inland region (including the municipalities of Karasjok and Kautokeino) and the coastal region (including the other eight municipalities), based on whether the municipalities include coastal areas or not (Fig. 1).

\section{Ethics approval}

The Regional Committee for Medical and Health Research Ethics of Northern Norway (REK-Nord) approved the SAMINOR 2 Clinical Survey. The storing of personal data for the SAMINOR 2 Clinical Survey was approved by the National Data Inspectorate. The application for the present research project was approved by the Regional Committee for Medical and Health Research Ethics of Northern Norway (REK-Nord). All participants signed an informed consent form.

\section{Statistical analysis}

We hypothesized that differences in food intake between Sami and non-Sami populations may still exist despite lifestyle changes, and that persons who regard themselves as multi-ethnic Sami (both Sami and Norwegian or other ethnic group) may have a food intake that is more similar to non-Sami than to those who regard themselves as being solely of Sami ethnicity. 
All data were analysed separately in males and females, and sample characteristics are presented by ethnic group. Ethnic comparisons were made using Pearson's $\chi^{2}$ test or the Mann-Whitney test. The intake of twenty-three defined food groups/foods items $(\mathrm{g} / \mathrm{d})$ is shown by sex and ethnic group. The distribution of food intake did not meet the assumption of normality. Medians and 25th-75th percentiles are given for descriptive purposes.

Non-parametric multiple quantile regression ${ }^{(32)}$ was used to detect the influence of Sami and multi-ethnic Sami $v$. non-Sami ethnicity (reference group) on food intake, with adjustment for age only and with adjustment for age, education, physical activity level, BMI, smoking and EI (tertiles; MJ). Median regression estimates the median of the dependent variable, conditional on the values of the independent variables, similarly to least-squares regression. Standard errors (95\% CI) of quantile regression coefficients were obtained using the bootstrap method (500 bootstrap replications were used). Age-adjusted and fully adjusted $\beta$ coefficients and $P$ values are presented.

The sample was stratified by region (inland and coastal) due to the well-known effect of region of residence on the intake of traditional Sami foods ${ }^{(20)}$. Differences in the consumption of lean fish, oily fish, freshwater fish, fish roe/liver and reindeer meat were estimated between ethnic groups in each geographical region. In addition, differences in the intake of total fish, lean fish, oily fish, freshwater fish, fish roe/liver and reindeer meat were estimated for the male and female sub-samples between the inland (reference group) and the coastal population groups. The same regression models were used. Data were analysed using the statistical software package Stata version 14. All tests were two-sided with a 5\% significance level.

\section{Results}

\section{Characteristics of the study sample}

The distribution of ethnic groups (non-Sami 61\%, multiethnic Sami 14\%, Sami 25\%) did not differ by sex. Multiethnic Sami females were slightly younger ( 54 years) than their non-Sami and Sami counterparts $(57$ years; $P=0.0002)$. In males, median age was similar across ethnic groups (57-58 years).

Approximately $40 \%$ of males had more than 13 years of education in all three ethnic groups. The proportion of non-Sami $v$. Sami females with more than 13 years of education was 50 and $53 \%$, respectively. However, a higher proportion of multi-ethnic Sami females reported more than 13 years of education (62\%). A similar proportion of current smokers was observed in all ethnic groups and for both sexes. Obesity rates (BMI $\geq 30 \mathrm{~kg} / \mathrm{m}^{2}$ ) were somewhat higher among Sami than among multiethnic Sami and non-Sami participants (34, 28 and 28\% in males and 35, 29 and $25 \%$ in females, respectively). The proportion of Sami males and females with a low level of physical activity was higher when compared with multiethnic Sami and non-Sami participants. Moreover, fewer multi-ethnic Sami (16\%) and Sami (15\%) females reported a high level of physical activity when compared with nonSami females (21\%; Table 1).

The minimum-maximum values of total EI were 1810$29812 \mathrm{~kJ}$ in males ( $n$ 2096) and $1460-32951 \mathrm{~kJ}$ in females ( $n$ 2505) before exclusion based on EI:BMR ${ }^{(27)}$. The minimum-maximum values of total $\mathrm{EI}$ in the final analytical sample were $3067-22096 \mathrm{~kJ}(3 \cdot 1-22 \cdot 1 \mathrm{MJ})$ in males and $2615-15131 \mathrm{~kJ}(2 \cdot 6-15 \cdot 1 \mathrm{MJ})$ in females. The distribution of ethnic groups differed by tertile of EI in males $(P<0.0001)$ and females $(P=0.008)$, with a higher proportion $(41 \%)$ of Sami males in the lowest tertile and a higher proportion of multi-ethnic Sami females (40\%) in the highest tertile.

The three ethnic groups were not equally distributed across the two geographical regions (Pearson's $\chi^{2}$ test, $P<0.0001)$. Thus, stratified analyses were done by region. In the inland region, $12 \%$ considered themselves non-Sami, $12 \%$ multi-ethnic Sami and 76\% Sami. Corresponding values for the coastal region were 75, 14 and $11 \%$ in nonSami, multi-ethnic Sami and Sami, respectively.

\section{Percentages of non-consumers of selected foods}

We assumed that some of the local food items in the FFQ were consumed to a limited degree. Thus, we recorded the percentage of non-consumers of freshwater fish, fish roe/liver, reindeer meat, moose meat, food made with animal blood, seagull eggs and tundra grouse by ethnic group (Table 2). Ethnic differences in non-consumption were detected in both males and females. We observed a strong gradient for all these local foods, with the fewest non-consumers among Sami, followed by multi-ethnic Sami and non-Sami, except for fish roe/liver, seagull eggs and tundra grouse. The difference in the proportion of non-consumers was particularly clear for reindeer meat. Intakes of seagull eggs and tundra grouse were very low in all ethnic groups; thus these food items were not selected for subsequent regression analyses. Only $7 \%$ of Sami males and $5 \%$ of Sami females did not consume reindeer meat. However, approximately one-third of the Sami participants did not consume freshwater fish, and half did not consume moose meat or food made with animal blood. Nevertheless, the proportions of non-consumers of these items were considerably higher in the non-Sami group.

\section{Impact of ethnicity on food intake}

Sami males consumed less vegetables, potatoes, total fish, lean fish, fish products, chicken, baked goods and salty snacks than their non-Sami counterparts. Conversely, intakes of fat as spread on bread, total coffee, freshwater fish, reindeer meat, moose meat and food made with animal blood were higher in Sami males than non-Sami 
males (Table 3). A similar pattern was observed in Sami females (Table 4).

The diet of multi-ethnic Sami males and females was more similar to the diet of participants who considered themselves non-Sami. However, some significant differences were seen: multi-ethnic Sami males ate less dairy products and baked goods, and more oily fish, freshwater fish and reindeer meat, than non-Sami males. Multi-ethnic Sami females ate less lean fish and fish products, and more reindeer meat, than non-Sami females.

\section{Impact of ethnicity on food intake in different geographical regions}

Stratified by inland/coastal region and sex, intakes of lean fish, oily fish, freshwater fish, fish roe/liver and reindeer meat were estimated and compared by ethnic group (Table 5). Sami ethnicity had a greater influence on the intake of reindeer meat in the inland region. Participants of Sami ethnicity from the inland region had the highest median intake of reindeer meat $(25 \mathrm{~g} / \mathrm{d}$ in both males and females). The median intake of reindeer meat was lower for multi-ethnic Sami from the inland region $(12 \mathrm{~g} / \mathrm{d}$ in both males and females) and non-Sami $(8 \mathrm{~g} / \mathrm{d}$ in both males and females). In the coastal region, the intake of reindeer meat was $7 \mathrm{~g} / \mathrm{d}$ in Sami males, $8 \mathrm{~g} / \mathrm{d}$ in Sami females, $5 \mathrm{~g} / \mathrm{d}$ in multi-ethnic Sami males and females, $4 \mathrm{~g} / \mathrm{d}$ in non-Sami males and $2 \mathrm{~g} / \mathrm{d}$ in non-Sami females.
No differences were found for lean fish and oily fish intakes between non-Sami and multi-ethnic Sami males and females, neither in the inland nor in the coastal region. However, in the coastal region, Sami males consumed more oily fish and more freshwater fish than their nonSami counterparts, although this was not the case in females. The highest oily fish intake was observed among Sami males in the coastal region $(27 \mathrm{~g} / \mathrm{d})$ and the highest freshwater fish intake was observed among Sami males from the inland region $(6 \mathrm{~g} / \mathrm{d})$. Sami males in the inland region and Sami males and females in the coastal region consumed less lean fish when compared with non-Sami from the same regions.

\section{Impact of geographical region on food intake}

The consumption of reindeer meat was considerably lower, and the consumption of lean fish was considerably higher, in the coastal region than in the inland region when all ethnic groups were combined (Table 6). Indeed, when the lean fish consumption of all ethnic groups in the coastal and inland regions were compared, males consumed 41 and $17 \mathrm{~g} / \mathrm{d}$, and females consumed 32 and $14 \mathrm{~g} / \mathrm{d}$, respectively. Oily fish intake was significantly higher in females living in the coastal region, but not in males. Fish roe/liver intake was higher in the coastal region and a higher freshwater fish intake was found in the inland region.

Table 1 Characteristics of the study sample by ethnicity and sex $(n$ 4504)* in the SAMINOR 2 Clinical Survey, 2012-2014

\begin{tabular}{|c|c|c|c|c|c|c|c|c|c|c|c|c|c|c|}
\hline \multirow[b]{3}{*}{ Characteristic } & \multicolumn{6}{|c|}{ Males (n 2054) } & \multirow[b]{3}{*}{$P \dagger$} & \multicolumn{6}{|c|}{ Females ( $n$ 2450) } & \multirow[b]{3}{*}{$P+$} \\
\hline & \multicolumn{2}{|c|}{$\begin{array}{l}\text { Non-Sami } \\
(n \text { 1248) }\end{array}$} & \multicolumn{2}{|c|}{$\begin{array}{l}\text { Multi-ethnic Sami } \\
\quad(n 286)\end{array}$} & \multicolumn{2}{|c|}{$\begin{array}{l}\text { Sami } \\
(n 520)\end{array}$} & & \multicolumn{2}{|c|}{$\begin{array}{l}\text { Non-Sami } \\
(n \text { 1495) }\end{array}$} & \multicolumn{2}{|c|}{$\begin{array}{l}\text { Multi-ethnic Sami } \\
\quad(n \text { 336) }\end{array}$} & \multicolumn{2}{|c|}{$\begin{array}{l}\text { Sami } \\
(n 619)\end{array}$} & \\
\hline & $n$ & $\%$ & $n$ & $\%$ & $n$ & $\%$ & & $n$ & $\%$ & $n$ & $\%$ & $n$ & $\%$ & \\
\hline \multicolumn{15}{|l|}{ Age groups (years) } \\
\hline $40-49$ & 316 & $25 \cdot 3$ & 82 & 28.7 & 118 & $22 \cdot 7$ & \multirow[t]{3}{*}{0.367} & 417 & $27 \cdot 9$ & 123 & $36 \cdot 6$ & 156 & $25 \cdot 2$ & \multirow[t]{3}{*}{0.001} \\
\hline $50-59$ & 386 & 30.9 & 90 & 31.5 & 174 & 33.5 & & 485 & 32.4 & 115 & $34 \cdot 2$ & 217 & $35 \cdot 1$ & \\
\hline $60-69$ & 546 & 43.8 & 114 & 39.9 & 228 & 43.8 & & 593 & 39.7 & 98 & $29 \cdot 2$ & 246 & 39.7 & \\
\hline \multicolumn{15}{|l|}{ Education (years) } \\
\hline$<13$ & 708 & 58.2 & 157 & 56.7 & 300 & $60 \cdot 1$ & \multirow[t]{2}{*}{0.616} & 729 & $50 \cdot 4$ & 123 & $37 \cdot 7$ & 274 & $46 \cdot 7$ & \multirow[t]{2}{*}{$<0.0001$} \\
\hline$\geq 13$ & 509 & 41.8 & 120 & 43.3 & 199 & 39.9 & & 718 & $49 \cdot 6$ & 203 & $62 \cdot 3$ & 313 & $53 \cdot 3$ & \\
\hline \multicolumn{15}{|l|}{ Geographical region } \\
\hline Inland & 53 & $4 \cdot 2$ & 45 & $15 \cdot 7$ & 333 & $64 \cdot 0$ & \multirow[t]{2}{*}{$<0.0001$} & 71 & $4 \cdot 7$ & 74 & $22 \cdot 0$ & 422 & $68 \cdot 2$ & \multirow[t]{2}{*}{$<0.0001$} \\
\hline Coastal & 1195 & $95 \cdot 8$ & 241 & $84 \cdot 3$ & 187 & $36 \cdot 0$ & & 1424 & $95 \cdot 3$ & 262 & 78.0 & 197 & 31.8 & \\
\hline \multicolumn{15}{|l|}{ Physical activity level } \\
\hline Low (1-3) & 245 & 19.9 & 56 & 19.9 & 129 & $25 \cdot 6$ & \multirow[t]{3}{*}{0.018} & 209 & 14.5 & 60 & $18 \cdot 1$ & 151 & $25 \cdot 3$ & \multirow[t]{3}{*}{$<0.0001$} \\
\hline Moderate (4-7) & 821 & 66.5 & 177 & 63.0 & 295 & 58.6 & & 935 & 65.0 & 217 & $65 \cdot 6$ & 356 & $59 \cdot 6$ & \\
\hline High $(8-10)$ & 168 & $13 \cdot 6$ & 48 & $17 \cdot 1$ & 79 & $15 \cdot 7$ & & 295 & 20.5 & 54 & $16 \cdot 3$ & 90 & $15 \cdot 1$ & \\
\hline \multicolumn{15}{|l|}{ BMI category } \\
\hline $\begin{array}{l}\text { Normal/overweight } \\
\left(<30 \mathrm{~kg} / \mathrm{m}^{2}\right)\end{array}$ & 901 & $72 \cdot 2$ & 206 & $72 \cdot 0$ & 343 & $66 \cdot 0$ & \multirow[t]{2}{*}{0.027} & 1117 & $74 \cdot 7$ & 238 & $70 \cdot 8$ & 405 & 65.4 & \multirow[t]{2}{*}{$<0.0001$} \\
\hline Obese $\left(\geq 30 \mathrm{~kg} / \mathrm{m}^{2}\right)$ & 347 & $27 \cdot 8$ & 80 & $28 \cdot 0$ & 177 & $34 \cdot 0$ & & 378 & $25 \cdot 3$ & 98 & $29 \cdot 2$ & 214 & 34.6 & \\
\hline \multicolumn{15}{|l|}{ Smoking status } \\
\hline Never & 436 & 35.1 & 109 & 38.5 & 174 & 33.7 & \multirow[t]{3}{*}{0.390} & 550 & $37 \cdot 2$ & 122 & 36.5 & 217 & 35.6 & 0.918 \\
\hline Former & 589 & $47 \cdot 4$ & 118 & 41.7 & 242 & $46 \cdot 8$ & & 600 & 40.6 & 132 & 39.5 & 254 & 41.7 & \\
\hline Current & 217 & $17 \cdot 5$ & 56 & $19 \cdot 8$ & 101 & 19.5 & & 328 & $22 \cdot 2$ & 80 & $24 \cdot 0$ & 138 & $22 \cdot 7$ & \\
\hline Energy intake (MJ) & & & & & & & & & & & & & & \\
\hline Tertile 1 & 379 & $30 \cdot 4$ & 96 & 33.6 & 210 & $40 \cdot 4$ & $<0.0001$ & 502 & 33.6 & 88 & $26 \cdot 2$ & 227 & $36 \cdot 7$ & 0.008 \\
\hline Tertile 2 & 451 & $36 \cdot 1$ & 81 & 28.3 & 153 & 29.4 & & 504 & 33.7 & 112 & 33.3 & 201 & 32.5 & \\
\hline Tertile 3 & 418 & 33.5 & 109 & 38.1 & 157 & 30.2 & & 489 & $32 \cdot 7$ & 136 & 40.5 & 191 & 30.9 & \\
\hline
\end{tabular}

*Subgroups may not total 4504 due to missing values.

†Differences in proportions between non-Sami, multi-ethnic Sami and Sami were tested by Pearson's $x^{2}$ test. 


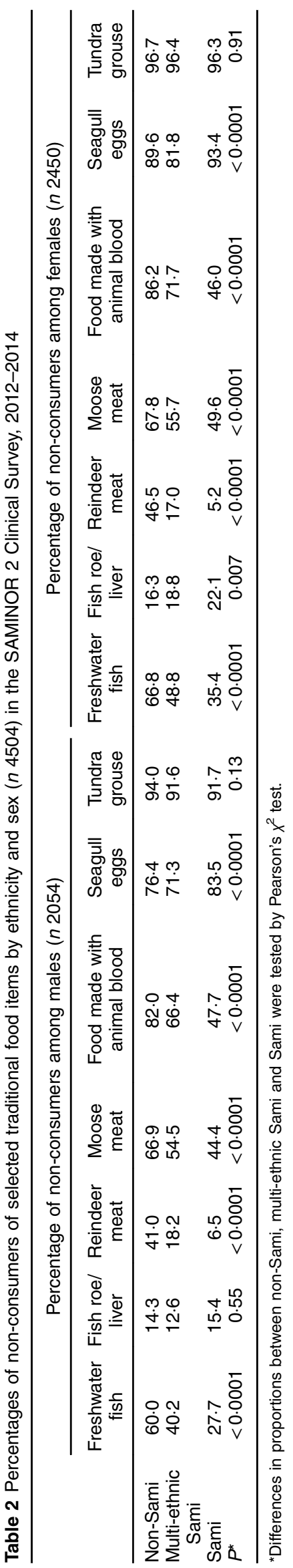

\section{Discussion}

To the best of our knowledge, the present study is the first large-scale, mixed-sex, population-based study on food intake which covers the extensive geographical area of northern Norway and focuses on ethnicity and the Indigenous Sami population. In the present paper we provide a comprehensive description and comparison of the intakes of main food groups/food items among males and females with non-Sami, multi-ethnic Sami and solely Sami self-perceived ethnicity. The present study shows that food intake among males and females with Sami ethnicity is different from that of non-Sami males and females. In addition, we observed that the diet of those who regarded themselves solely as Sami differed more from that of nonSami than did the diet of those who perceived themselves as multi-ethnic Sami, especially with respect to intake of reindeer meat in the inland region. Additionally, geographical area of residence was a strong determinant of fish, fish roe/liver and reindeer meat consumption.

Our reference non-Sami population resided in the same rural geographical areas as the Sami and multi-ethnic Sami populations. However, this non-Sami population may differ from those in urban or other rural areas in terms of diet. The studied non-Sami population may have better access to traditional Sami food items and may have a greater acceptance of the dietary habits of Sami culture. Also, individuals who regard themselves as non-Sami, but have Sami ancestors, may have retained parts of that culture, such as certain dietary habits. Nevertheless, we found that the average consumption of reindeer meat, moose meat and food made with animal blood was higher in Sami males and females. As expected, the consumption of reindeer meat was the highest among Sami males $(25.0 \mathrm{~g} / \mathrm{d})$ and females $(25.0 \mathrm{~g} / \mathrm{d})$ who live in the inland region (Finnmark County), as reindeer herding takes place primarily in this geographical area. The latest study on daily reindeer consumption among reindeer-herding Sami in Finnmark County was carried out by the Norwegian Radiation Protection Authority (year 2002), which aimed to investigate ${ }^{137} \mathrm{Cs}$ and ${ }^{90} \mathrm{Sr}$ deposition ${ }^{(18)}$. According to that report, the median consumption of reindeer meat (not including blood and organs) was $74 \mathrm{~g} / \mathrm{d}$. The difference with the intake of reindeer meat in our present study may be attributable to differences in methodology, sample size and the studied population group. Indeed, both the FFQ and the calculation of reindeer meat intake were different in the present and the aforementioned study. Additionally, our population was not restricted to reindeer-herding Sami. It is likely that Sami participants who are not involved in reindeer herding eat less reindeer meat. It is also possible that the consumption of reindeer meat is decreasing in this Indigenous population.

We found that geographical area of residence was an important factor associated with the intake of reindeer meat. In fact, in the coastal region the median consumption of 
Table 3 Food intake (g/d) by non-Sami, multi-ethnic Sami and Sami males ( $n$ 2054) in the SAMINOR 2 Clinical Survey, 2012-2014

\begin{tabular}{|c|c|c|c|c|c|c|c|c|c|c|c|c|c|c|c|c|}
\hline \multirow[b]{2}{*}{ Food } & \multicolumn{2}{|c|}{ Entire study sample } & \multicolumn{2}{|c|}{$\begin{array}{l}\text { Non-Sami males } \\
\quad(n \text { 1248) }\end{array}$} & \multicolumn{2}{|c|}{$\begin{array}{l}\text { Multi-ethnic Sami } \\
\text { males } \\
(n \text { 286) }\end{array}$} & \multicolumn{2}{|c|}{$\begin{array}{c}\text { Age-adjusted: } \\
\text { multi-ethnic Sami } v \text {. } \\
\text { non-Sami males (ref.) }\end{array}$} & \multicolumn{2}{|c|}{$\begin{array}{c}\text { Fully adjusted: } \\
\text { multi-ethnic Sami } v \text {. } \\
\text { non-Sami males (ref.) }\end{array}$} & \multicolumn{2}{|c|}{$\begin{array}{l}\text { Sami males } \\
\quad(n \text { 520) }\end{array}$} & \multicolumn{2}{|c|}{$\begin{array}{l}\text { Age-adjusted: } \\
\text { Sami v. non-Sami males } \\
\text { (ref.) }\end{array}$} & \multicolumn{2}{|c|}{$\begin{array}{l}\text { Fully adjusted: } \\
\text { Sami } v \text {. non-Sami } \\
\text { males (ref.) }\end{array}$} \\
\hline & Median & P25-P75 & Median & P25-P75 & Median & P25-P75 & $\beta^{*}$ & $P^{\star}$ & $\beta^{*}, \dagger$ & $P^{*}, \dagger$ & Median & P25-P75 & $\beta^{*}$ & $P^{\star}$ & $\beta^{*}, \dagger$ & $P^{*}, \dagger$ \\
\hline Vegetables & $115 \cdot 4$ & $63.9-184.3$ & 120.5 & $69 \cdot 2-192 \cdot 8$ & $120 \cdot 3$ & $68 \cdot 3-190 \cdot 9$ & -0.1 & 0.99 & $-6 \cdot 2$ & 0.37 & $100 \cdot 8$ & $51 \cdot 8-158.5$ & $-21 \cdot 1$ & 0.001 & -13.9 & 0.01 \\
\hline Fruit a & $162 \cdot 2$ & $86.5-$ & 159.3 & $85.2-253.9$ & 166.4 & $95.9-243.9$ & 8.6 & 0.30 & -3.6 & 0.69 & 162.6 & 88.2 & 0.9 & 1 & 0. & 0.21 \\
\hline otato & 110.2 & $74.3-209.9$ & 112.9 & $74 \cdot 3-209 \cdot 9$ & 110.2 & 56.2 & -4.5 & 0.55 & -3.3 & 0. & 94.5 & $56 \cdot 2-173 \cdot 3$ & $-20 \cdot 2$ & $<0.0001$ & -12.9 & 0.006 \\
\hline Dairy products & $272 \cdot 7$ & $128 \cdot 1-580 \cdot 3$ & $281 \cdot 8$ & $133 \cdot 8-580 \cdot 0$ & 251.5 & $100 \cdot 0-574.9$ & -29.0 & 0.17 & -57.5 & 0.03 & $272 \cdot 0$ & $126 \cdot 6-585 \cdot 8$ & $-15 \cdot 3$ & 0.47 & -3.9 & 0.84 \\
\hline Total fish & 67.2 & $42 \cdot 1-104 \cdot 7$ & 70.9 & $44.2-108.5$ & 71.4 & $47 \cdot 2-111 \cdot 6$ & 3.5 & 0.36 & 3.7 & 0.38 & 55.5 & $33.4-91.5$ & $-15 \cdot 2$ & $<0.0001$ & -12.2 & $<0.0001$ \\
\hline Lean fish & 33.1 & $15 \cdot 8-63 \cdot 1$ & 40.8 & $19 \cdot 5-70 \cdot 1$ & 37.8 & $21 \cdot 2-66 \cdot 9$ & $-4.6 \times 10^{-14}$ & 1.0 & 0.1 & 0.98 & 19.0 & $8 \cdot 0-39 \cdot 6$ & -21.9 & $<0.0001$ & -20.0 & $<0.0001$ \\
\hline Q Pilvf & 23.4 & $12 \cdot 4-37 \cdot 6$ & $23 \cdot 1$ & $11.5-36.6$ & $24 \cdot 3$ & $15 \cdot 7-40 \cdot 1$ & 0.8 & 0.64 & 2.8 & 0. & $23 \cdot 3$ & $12 \cdot 2-$ & 0.1 & & $1 \cdot 1$ & 0.39 \\
\hline Fish products & 29.8 & $16.5-51.5$ & 33.0 & $18.1-55.0$ & 29.9 & $16 \cdot 6-52 \cdot 9$ & $-3 \cdot 1$ & 0.16 & 0.7 & 0.7 & 23.0 & $11.6-44.7$ & $-10 \cdot 2$ & $<0.0001$ & -6.6 & $<0.0001$ \\
\hline $\begin{array}{l}\text { Red meat/meat } \\
\text { products }\end{array}$ & $72 \cdot 7$ & $47.7-101.5$ & 74.4 & $50 \cdot 1-102 \cdot 8$ & $77 \cdot 1$ & $48 \cdot 1-105 \cdot 6$ & 0.1 & 0.99 & 1.1 & 0.7 & 66.0 & $43 \cdot 1-93 \cdot 8$ & -10.0 & $<0.0001$ & $-4 \cdot 1$ & 0.10 \\
\hline Sauces & 23.0 & $12 \cdot 3-38 \cdot 3$ & $23 \cdot 1$ & $12 \cdot 4$ & $24 \cdot 3$ & $12 \cdot 9$ & 1.1 & 0.53 & 0.9 & 0.50 & $21 \cdot 3$ & $11 \cdot 1-38 \cdot 3$ & -1.4 & 0.33 & 0.2 & 0.82 \\
\hline Chicken & 11.1 & $4.6-18.1$ & $11 \cdot 1$ & $4.6-$ & 11.1 & 4.6 & $5.8 \times 10^{-15}$ & 1.0 & -1.3 & 0.22 & 6.4 & $0.0-16.2$ & $5.3 \times 10^{-15}$ & 1.0 & -1.9 & 0.004 \\
\hline Cereal, excl. bread & $59 \cdot 2$ & $32 \cdot 1-97 \cdot 2$ & $62 \cdot 6$ & $33.7-97.7$ & $59 \cdot 0$ & $30 \cdot 2-94 \cdot 4$ & -0.9 & 0.84 & $-2 \cdot 0$ & 0.61 & $54 \cdot 3$ & $27.4-93.5$ & $-8 \cdot 2$ & 0.019 & -0.04 & 1.0 \\
\hline Bread and crispbread & 180.0 & $102 \cdot 6-195 \cdot 1$ & $180 \cdot 0$ & $104 \cdot 4-193 \cdot 3$ & $180 \cdot 0$ & $100 \cdot 0-210 \cdot 6$ & $-7.8 \times 10^{-16}$ & 1.0 & 0.5 & 0.5 & 175.0 & $100 \cdot 0-1$ & -5.0 & 0.62 & 0.7 & 0.80 \\
\hline pread on bread & $18 \cdot 6$ & $8 \cdot 6-29 \cdot 6$ & 18.0 & $7.9-26.9$ & 20.0 & $8 \cdot 6-30.0$ & $2 \cdot 1$ & 0.19 & 0.04 & 0.98 & 20.0 & $9 \cdot 3-30.0$ & 2.3 & 0.15 & 3.2 & 0.001 \\
\hline Total c & $945 \cdot 0$ & $630 \cdot 0-1383 \cdot 5$ & $945 \cdot 0$ & $580.5-1365.0$ & 945.0 & $630 \cdot 0-1365.0$ & $9.6 \times 10^{-14}$ & 1.0 & $1.1 \times 10^{-14}$ & 1.0 & 1365.0 & $945 \cdot 0-1680 \cdot 0$ & 315 & 0.004 & 210 & $<0.0001$ \\
\hline Baked goods & 35.7 & $21 \cdot 0-51 \cdot 1$ & $36 \cdot 3$ & $21.4-51.6$ & 34.4 & $20.0-51.5$ & -3.3 & 0.017 & $-4 \cdot 3$ & 0.01 & 33.0 & $17.3-45.8$ & $-3 \cdot 3$ & 0.010 & -3.6 & 0.01 \\
\hline Salty snacks & 5.0 & $2 \cdot 0-10 \cdot 0$ & $6 \cdot 7$ & $2 \cdot 0-1$ & $5 \cdot 0$ & $2 \cdot 0$ & $4.5 \times 10^{-15}$ & 1.0 & -0.3 & 0.6 & 4.0 & & $-2 \cdot 7$ & $<0.0001$ & -1.9 & $<0.0001$ \\
\hline Sweets & $30 \cdot 1$ & $15 \cdot 3-54 \cdot 6$ & $32 \cdot 0$ & $15 \cdot 8-55 \cdot 8$ & $27 \cdot 7$ & $15 \cdot 4-53 \cdot 2$ & $-4 \cdot 3$ & 0.014 & $-3 \cdot 3$ & 0.1 & $27 \cdot 2$ & $13 \cdot 7-51 \cdot 3$ & $-5 \cdot 4$ & 0.001 & $-2 \cdot 3$ & 0.15 \\
\hline \multicolumn{17}{|l|}{ Traditional food items } \\
\hline $\begin{array}{l}\text { Freshwater fis } \\
\text { Fish roe/liver }\end{array}$ & $\begin{array}{l}1.1 \\
1.0\end{array}$ & $0.8-2.4$ & 1.0 & $0 \cdot 8-2 \cdot 4$ & 1.0 & $0 \cdot 8-2 \cdot 8$ & $-3.0 \times 10^{-16}$ & $\begin{array}{l}<0.000 \\
1.0\end{array}$ & $\begin{array}{l}1.5 \\
0.07\end{array}$ & $\begin{array}{l}0.01 \\
0.28\end{array}$ & $\begin{array}{l}4.7 \\
0.9\end{array}$ & $\begin{array}{l}0.0-13.5 \\
0.6-2.4\end{array}$ & $\begin{array}{r}4.7 \\
-0.1\end{array}$ & $\begin{array}{r}<0.000 \\
0.06\end{array}$ & $\begin{aligned} & 4.7 \\
&-0.05\end{aligned}$ & $\begin{array}{l}<0.0001 \\
0.39\end{array}$ \\
\hline Reindeer meat & $5 \cdot 3$ & $0 \cdot 0-12 \cdot 3$ & 3.5 & $0 \cdot 0-7 \cdot 0$ & 7.0 & $3 \cdot 5-12 \cdot 3$ & & $<0.0001$ & 3.5 & $<0.0001$ & $16 \cdot 4$ & $7.0-37.5$ & 11.1 & $<0.0001$ & 11.1 & $<0.0001$ \\
\hline Moose meat & 0.0 & $0.0-5 \cdot 3$ & 0.0 & $0.0-5 \cdot 3$ & 0.0 & $0.0-7.0$ & $4.0 \times 10^{-15}$ & 1.0 & $5.4 \times 10^{-15}$ & 1.0 & 3.5 & $0.0-8.8$ & 3.5 & $<0.0001$ & 3.5 & $<0.0001$ \\
\hline Food made with & 0.0 & $0.0-5 \cdot 0$ & 0.0 & $0 \cdot 0-0 \cdot 0$ & 0.0 & $0 \cdot 0-5 \cdot 0$ & $2 \cdot 2 \times 10^{-14}$ & 0.035 & $-2 \cdot 3 \times 10^{-15}$ & 0.75 & $5 \cdot 0$ & $0 \cdot 0-5 \cdot 0$ & $5 \cdot 0$ & $<0.0001$ & 5.0 & $<0.0001$ \\
\hline
\end{tabular}

P25, 25th percentile; P75, 75th percentile; ref., reference category.

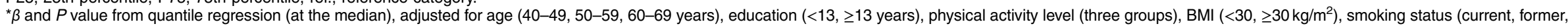
never) and energy intake (tertiles; $M J)$.

tin bold font if statistically significant in the fully adjusted model. 
reindeer meat was approximately $20 \mathrm{~g} / \mathrm{d}$ lower when compared with the inland region.

In the small study by Nilsen et al. from 1999, dietary history was obtained during interviews with Sami living in Finnmark Country (municipalities of Kautokeino, Karasjok and Tana) and with Norwegians living in the small city of Alta $^{(17)}$. When compared with Norwegians, Sami (mixedsex sample, adjusted for age and sex) received a higher proportion of their energy from total red meat (reindeer meat was included in calculation) and reindeer meat as estimated separately. Intakes of oily fish, fat added to food (mainly margarine on bread), coffee, sugar with coffee and dairy butter were also higher among Sami. The Norwegians received more energy from lean fish, fish products, dairy products, pork, beef, vegetables and fruits, and total fish intake was not different between Sami and Norwegians $^{(17)}$. To some extent, our findings were consistent with these previous results. We found that Sami males and females consumed less vegetables, lean fish and fish products; and more fat as spread on bread, coffee, freshwater fish, reindeer meat, moose meat and food made with animal blood. We also found that Sami males and females consumed less total fish, chicken, baked goods and salty snacks than their non-Sami counterparts. Additionally, Sami females ate less oily fish and red meat (pork, beef and mutton)/meat products, and Sami males consumed fewer potatoes than their non-Sami counterparts. Interestingly, red meat estimated as the consumption of pork, beef, mutton and meat products did not differ between Sami and non-Sami males. Compared with Nilsen et al.'s study, we did not find differences in the consumption of dairy and fruits for both sexes. It is possible that the consumption of these products has increased among Sami.

Food and food traditions are often described as important carriers, markers and tools for cultural identity and belonging. Food provides nutrients, but what we eat and our food traditions also nourish cultural and ethnic identity and belonging. Our results indicate that having self-perceived Sami ethnicity implies stronger ties to Sami reindeer-herding food traditions in the inland region, which is consistent with the previous results from dietary studies among Sami adolescents ${ }^{(33)}$ and Sami adults ${ }^{(20)}$ living in northern Norway. Reindeer meat, moose meat, food made with animal blood and freshwater fish are traditional foods that remain important in Sami culture. Higher intakes of traditional meats and food made with animal blood may contribute to a higher concentration of nutrients like $\mathrm{Fe}^{(19,33)}$ and vitamin $\mathrm{B}_{12}$ among the Sami in northern Norway.

In the present paper, we applied region-stratified statistical analysis, because previous studies have shown that diet may have stronger relationship with geographical area than with ethnicity ${ }^{(20)}$. As expected, our results showed that the coastal population ate more total fish, lean fish and fish liver/roe; and that the inland population ate more reindeer meat and local freshwater fish. Comparison of oily fish intake between the coastal region and the inland region did not provide a clear result. When we considered the coastal regions in Finnmark County alone (municipalities of Porsanger, Tana and Nesseby), the oily fish intake was higher by approximately $4 \mathrm{~g} / \mathrm{d}$ among males and females (data not shown). However, when the coastal region included Finnmark, Troms and Nordland counties, the oily fish intake was significantly higher in females, but not in males. We found that the inland population eats more freshwater fish. However, the consumption of freshwater fish was generally low and did not contribute much to the total fish intake of Sami living in the inland region. In our study, the average freshwater fish consumption among Sami males and females living in the inland regions was considerably lower $(6.0 \mathrm{~g} / \mathrm{d}$ in males and $3.9 \mathrm{~g} / \mathrm{d}$ in females) than that previously reported among reindeer-herding Sami males and females $(18 \mathrm{~g} / \mathrm{d})^{(18)}$.

Lifestyle changes within the last century have brought about a rapid transition in nutrition, characterized by a decreasing consumption of traditional foods and an associated increase in the consumption of processed, shopbought foods. These changes have also been observed in non-Indigenous populations, but the negative effects are suggested to affect the Indigenous populations to a larger degree $^{(8,34)}$. In fact, a high prevalence of obesity and metabolic syndrome was found in the SAMINOR 1 Survey in both the Sami and the non-Sami populations of rural northern Norway ${ }^{(35,36)}$. The prevalence of obesity was higher in Sami females ${ }^{(35)}$ and the prevalence of metabolic syndrome was higher in Sami females younger than 50 years than their non-Sami counterparts ${ }^{(36)}$. However, there was an overall lower prevalence of metabolic syndrome in Sami males compared with non-Sami males ${ }^{(36)}$. Even though Sami women were more obese, no differences in the incidence of diabetes mellitus have been found between Sami and Norwegian populations based on 14 years of follow-up (in the period 1974-1989) ${ }^{(37)}$. Similarly, no ethnic differences in the prevalence of diabetes between Sami and non-Sami populations have been reported in the SAMINOR 1 Survey $(2003-2004)^{(36)}$. Overall, age-standardized prevalence of diabetes mellitus in Sami males and females was 5.5 and $4.8 \%$, respectively $^{(38)}$. When data from the SAMINOR 1 Survey were stratified by region, Sami males living in the inland region and Sami females living in Porsanger, Tana and Nesseby municipalities had lower prevalence of diabetes mellitus ( $2 \cdot 8$ and $2 \cdot 4 \%$, respectively) compared with their nonSami counterparts ( 8.6 and $4.7 \%$, respectively). However, the opposite result was seen for both Sami males (9.3\%) and females $(7.7 \%)$ living in the southern-most region, where Sami participants constituted the minority ${ }^{(38)}$. Indeed, dietary patterns were associated with insulin resistance and cardiometabolic risk in other Indigenous populations ${ }^{(39,40)}$. The diet and lifestyle factors in relation 
Table 4 Food intake $(\mathrm{g} / \mathrm{d})$ in non-Sami, multi-ethnic Sami and Sami females ( $n$ 2450) in the SAMINOR 2 Clinical Survey, 2012-2014

\begin{tabular}{|c|c|c|c|c|c|c|c|c|c|c|c|c|c|c|c|c|}
\hline \multirow[b]{2}{*}{ Food } & \multicolumn{2}{|c|}{ Entire study sample } & \multicolumn{2}{|c|}{$\begin{array}{c}\text { Non-Sami females } \\
(n \text { 1495) }\end{array}$} & \multicolumn{2}{|c|}{$\begin{array}{l}\text { Multi-ethnic Sami } \\
\text { females } \\
(n \text { 336) }\end{array}$} & \multicolumn{2}{|c|}{$\begin{array}{c}\text { Age-adjusted: } \\
\text { multi-ethnic Sami } v \text {. } \\
\text { non-Sami females (ref.) }\end{array}$} & \multicolumn{2}{|c|}{$\begin{array}{c}\text { Fully adjusted: } \\
\text { multi-ethnic Sami } v \text {. } \\
\text { non-Sami females (ref.) }\end{array}$} & \multicolumn{2}{|c|}{$\begin{array}{l}\text { Sami females } \\
\quad(n \text { 619) }\end{array}$} & \multicolumn{2}{|c|}{$\begin{array}{l}\text { Age-adjusted: } \\
\text { Sami } v \text {. non-Sami } \\
\text { females (ref.) }\end{array}$} & \multicolumn{2}{|c|}{$\begin{array}{l}\text { Fully adjusted: } \\
\text { Sami } v \text {. non-Sami } \\
\text { females (ref.) }\end{array}$} \\
\hline & Median & P25-P75 & Median & P25-P75 & Median & P25-P75 & $\beta^{*}$ & $P^{*}$ & $\beta^{*}, \dagger$ & $P^{\star}, \dagger$ & Median & P25-P75 & $\beta^{*}$ & $P^{\star}$ & $\beta^{\star}, \dagger$ & $P^{*}, \dagger$ \\
\hline Vegetables & 166.4 & $104 \cdot 2-249 \cdot 0$ & 174.7 & $112 \cdot 2-258 \cdot 0$ & 173.5 & $113.4-250.0$ & -1.4 & 0.87 & -6.8 & 0.40 & 147.1 & $81 \cdot 6-229 \cdot 1$ & -27.4 & $<0.0001$ & $-34 \cdot 3$ & $<0.0001$ \\
\hline Fruit and berries & $190 \cdot 3$ & $117 \cdot 0-288 \cdot 4$ & 191.3 & $122.8-291 \cdot 7$ & 191.8 & $113.5-283.9$ & -0.5 & 0.96 & 0.7 & 0.94 & $186 \cdot 3$ & $101 \cdot 8-282 \cdot 7$ & -2.5 & 0.78 & 1.4 & 0.85 \\
\hline Potatoes & 82.1 & $56 \cdot 2-102 \cdot 3$ & 88.9 & $56 \cdot 2-102 \cdot 3$ & 74.3 & $56.2-94.5$ & $-7.6 \times 10^{-15}$ & 1.0 & -5.6 & 0.09 & 74.3 & $56.2-94.5$ & $4.1 \times 10^{-15}$ & 1.0 & -2.6 & 0.33 \\
\hline Dairy products & 206.9 & $96 \cdot 4-340 \cdot 3$ & 210.7 & $96 \cdot 3-331 \cdot 6$ & 221.6 & $98 \cdot 5-420 \cdot 3$ & 15.0 & 0.27 & 9.5 & 0.48 & 187.0 & $96 \cdot 5-329 \cdot 1$ & -20.0 & 0.08 & 0.8 & 0.93 \\
\hline Total fish & 55.8 & $32.0-84.8$ & 58.1 & $34.1-87.2$ & 58.4 & $34.3-83.0$ & -0.6 & 0.83 & -0.1 & 0.97 & 47.2 & $25.6-79.5$ & -9.8 & $<0.0001$ & -8.4 & 0.001 \\
\hline Lean fish & 27.2 & $11.8-48.9$ & 31.5 & $15 \cdot 2-54 \cdot 3$ & 27.6 & $11.9-47.3$ & -3.8 & 0.03 & -4.7 & 0.003 & 17.0 & $6.3-37.8$ & -13.8 & $<0.0001$ & -11.8 & $<0.0001$ \\
\hline Oily fish & 19.9 & $9.7-32 \cdot 8$ & 20.3 & $9.5-32.9$ & 22.0 & $12.7-35.8$ & 2.8 & 0.07 & $2 \cdot 1$ & 0.11 & 16.7 & $8 \cdot 4-29 \cdot 4$ & -2.5 & 0.003 & -2.3 & 0.03 \\
\hline Fish products & 29.0 & $15 \cdot 3-47 \cdot 4$ & 32.1 & $17.4-49.2$ & $28 \cdot 3$ & $15 \cdot 8-47 \cdot 4$ & -4.2 & 0.04 & -5.4 & 0.001 & 22.4 & $9.9-41.5$ & -9.2 & $<0.0001$ & -8.5 & $<0.0001$ \\
\hline $\begin{array}{l}\text { Red meat/meat } \\
\text { products }\end{array}$ & 50.4 & $33.2-71.0$ & 51.1 & $34 \cdot 8-72 \cdot 1$ & 54.0 & $35 \cdot 8-74.5$ & 1.4 & 0.52 & 0.4 & 0.82 & 45.7 & $28 \cdot 7-67 \cdot 2$ & $-6 \cdot 2$ & $<0.0001$ & -5.5 & 0.001 \\
\hline Sauces & 17.8 & $9 \cdot 9-30 \cdot 2$ & $17 \cdot 4$ & $9 \cdot 9-30 \cdot 2$ & $21 \cdot 1$ & $12 \cdot 3-32 \cdot 5$ & 3.01 & 0.03 & 1.5 & 0.13 & $17 \cdot 2$ & $8 \cdot 8-29 \cdot 3$ & -0.1 & 0.89 & -0.7 & 0.39 \\
\hline Chicken & 11.6 & $4 \cdot 6-20 \cdot 0$ & 11.6 & $6 \cdot 4-$ & 11.6 & $6.4-26.5$ & $4.5 \times 10^{-15}$ & 1.0 & -0.04 & 0.96 & 11.1 & $4.6-$ & $\begin{array}{l}-1.9 \\
-1.9\end{array}$ & 0.22 & -1.9 & 0.004 \\
\hline Cereal, excl. br & 70.8 & $41 \cdot 1-108 \cdot 6$ & 70.0 & $40 \cdot 2-106 \cdot 4$ & 74.6 & $41 \cdot 7-122 \cdot 7$ & 3.1 & 0.4 & 3.3 & 0. & 68.6 & 41.7 & $2 \cdot 1$ & 0.4 & 3.4 & 0.21 \\
\hline Bread and crispbread & 110.5 & $69 \cdot 4-180 \cdot 0$ & 110.5 & $64 \cdot 9-180 \cdot 0$ & 121.9 & $77 \cdot 0-184 \cdot 4$ & $12 \cdot 1$ & 0.07 & 11.9 & 0.05 & 110.5 & $65 \cdot 8-180.0$ & $-7.8 \times 10^{-15}$ & 1.0 & 5.8 & 0.25 \\
\hline $\begin{array}{l}\text { Fat as spread on } \\
\text { bread }\end{array}$ & 14.3 & $4 \cdot 3-24 \cdot 3$ & 13.5 & $3.8-22.5$ & 14.6 & $4 \cdot 3-24 \cdot 3$ & 1.8 & 0.002 & 1.0 & 0.32 & 14.6 & $6.8-25 \cdot 0$ & 1.8 & 0.002 & 2.2 & 0.01 \\
\hline Total coffee & $945 \cdot 0$ & $525 \cdot 0-1365 \cdot 0$ & $945 \cdot 0$ & $525 \cdot 0$ & $945 \cdot 0$ & $525 \cdot 0$ & 0 & 1.0 & $81 \cdot 7$ & 0.12 & $945 \cdot 0$ & $525.0-1365.0$ & 0 & 1.0 & 163.3 & $<0.0$ \\
\hline Baked goods & 32.9 & $18 \cdot 2-44 \cdot 8$ & 34.8 & $20 \cdot 6-47 \cdot 4$ & 32.1 & $14 \cdot 9-44 \cdot 1$ & -2.8 & 0.12 & -3.3 & 0.05 & 30.1 & $14.7-41.9$ & -3.2 & 0.01 & -3.4 & 0.004 \\
\hline Salty snacks & 5.0 & $2.0-10.7$ & 6.7 & $2 \cdot 0-12 \cdot 0$ & 7.0 & $2.7-12 \cdot 4$ & $-1.4 \times 10^{-15}$ & 1.0 & -0.3 & 0.57 & 4.3 & $0.0-9.0$ & -2.7 & $<0.0001$ & -2.4 & $<0.0001$ \\
\hline $\begin{array}{l}\text { Sweets } \\
\text { Traditional food items }\end{array}$ & $24 \cdot 0$ & $11 \cdot 4-42 \cdot 1$ & 23.4 & $11 \cdot 2-41 \cdot 8$ & 24.5 & $12 \cdot 9-41 \cdot 7$ & 1.2 & 0.56 & -0.2 & 0.88 & 24.4 & $11 \cdot 1-44 \cdot 0$ & 0.9 & 0.50 & 0.6 & 0.68 \\
\hline \multicolumn{17}{|l|}{ Traditional food items } \\
\hline Fish roe/liver & 0.9 & $\begin{array}{l}0.0-4.0 \\
0.6-1.7\end{array}$ & $\begin{array}{l}0.0 \\
0.9\end{array}$ & $0.6-1.7$ & $\begin{array}{l}0.9 \\
0.9\end{array}$ & $\begin{array}{l}0.0-4 \cdot 7 \\
0.6-1 \cdot 8\end{array}$ & $-2.2 \times 10^{-16}$ & 1.0 & 0.012 & $\begin{array}{l}0.08 \\
0.65\end{array}$ & $\begin{array}{l}3.0 \\
0.9\end{array}$ & $\begin{array}{l}0.2-9.0 \\
0.1 .1\end{array}$ & $\begin{array}{l}3.0 \\
-1.4 \times 10^{-16}\end{array}$ & $\begin{array}{l}<0.0001 \\
1.0\end{array}$ & $\begin{aligned} & 3.0 \\
- & 0.02\end{aligned}$ & 0.32 \\
\hline Reind & 4.1 & $0.0-$ & 1.8 & $0.0-$ & $5 \cdot 3$ & $3 \cdot 5-12 \cdot 3$ & 3.5 & $<0.0001$ & & $<0.0001$ & 16.4 & $8.2-37.5$ & $12 \cdot 9$ & 0.001 & 12.2 & $<0.0001$ \\
\hline Moos & 0.0 & $0.0-5 \cdot 3$ & 0.0 & $0.0-$ & 0.0 & $0.0-5 \cdot 3$ & $-1.7 \times 10^{-16}$ & 1.0 & $1.0 \times 10^{-17}$ & 1.0 & 1.8 & $0.0-7.0$ & 1.8 & $<0.0001$ & 1.8 & $<0.0001$ \\
\hline $\begin{array}{l}\text { Food made with } \\
\text { animal blood }\end{array}$ & 0.0 & $0.0-5.0$ & 0.0 & $0.0-0.0$ & 0.0 & $0.0-5.0$ & $-1.8 \times 10^{-14}$ & 0.24 & $1.95 \times 10^{-15}$ & 0.86 & 5.0 & $0.0-5.0$ & 5.0 & $<0.0001$ & 5.0 & $<0.0001$ \\
\hline
\end{tabular}

$\mathrm{P} 25$, 25th percentile; $\mathrm{P} 75,75$ th percentile; ref., reference category.

${ }^{*} \beta$ and $P$ value from quantile regression (at the median), adjusted for age (40-49, 50-59, 60-69 years), education $\left(<13, \geq 13\right.$ years), physical activity level (three groups), BMl (<30, $\left.\geq 30 \mathrm{~kg} / \mathrm{m}^{2}\right)$, smoking status (current,

former, never) and energy intake (tertiles; MJ).
tln bold font if statistically significant in the fully adjusted model. 
Table 5 Selected food intake (g/d) in non-Sami, multi-ethnic Sami and Sami participants, stratified by inland/coastal region and sex ( $n$ 4504), in the SAMINOR 2 Clinical Survey, 2012-2014

\begin{tabular}{|c|c|c|c|c|c|c|c|c|c|c|c|c|c|c|c|c|c|c|c|c|}
\hline & \multicolumn{10}{|c|}{ Males ( $n$ 2054) } & \multicolumn{10}{|c|}{ Females ( $n$ 2450) } \\
\hline & \multicolumn{2}{|c|}{ Lean fish } & \multicolumn{2}{|c|}{ Oily fish } & \multicolumn{2}{|c|}{ Freshwater fish } & \multicolumn{2}{|c|}{ Fish roe/liver } & \multicolumn{2}{|c|}{ Reindeer meat } & \multicolumn{2}{|c|}{ Lean fish } & \multicolumn{2}{|c|}{ Oily fish } & \multicolumn{2}{|c|}{ Freshwater fish } & \multicolumn{2}{|c|}{ Fish roe/liver } & \multicolumn{2}{|c|}{ Reindeer meat } \\
\hline & Median & P25-P75 & Median & $P 25-P 75$ & Median & P25-P75 & Median & P25-P75 & Median & P25-P75 & Median & P25-P75 & Median & P25-P75 & Median & P25-P75 & Median & P25-P75 & Median & $\mathrm{P} 25-\mathrm{P} 75$ \\
\hline \multicolumn{21}{|l|}{ Inland region } \\
\hline Non-Sami & $26 \cdot 2$ & $11 \cdot 8-41.4$ & 20.3 & $14.9-38.4$ & 4.0 & $0 \cdot 0-9.4$ & 0.9 & $0.6-1 \cdot 1$ & 8.2 & $5 \cdot 3-12 \cdot 3$ & 18.8 & $7.6-34.5$ & 23.9 & $12.4-35.9$ & $1 \cdot 1$ & $0.0-6.0$ & 0.8 & $0.2-1.3$ & 8.2 & $3.5-12.5$ \\
\hline Multi-ethnic & 21.7 & $11 \cdot 0-37 \cdot 8$ & 20.9 & $14.7-33.8$ & 4.0 & $0.0-12 \cdot 0$ & 0.9 & $0.0-1 \cdot 7$ & $12 \cdot 5$ & $8 \cdot 2-50.0$ & 14.1 & $6 \cdot 3-30 \cdot 4$ & 21.2 & $10.7-32.2$ & 1.5 & $0.0-7 \cdot 9$ & 0.7 & $0.0-0.9$ & $12 \cdot 3$ & $5 \cdot 3-35 \cdot 0$ \\
\hline \multirow{2}{*}{\multicolumn{3}{|c|}{ Multi-ethnic Sami $v \cdot$ non-Sami (ref.) }} & 20.8 & $10 \cdot 7-34.0$ & 6.0 & $1.1-15.8$ & 0.9 & $0.3-1 \cdot 9$ & 25.0 & $12 \cdot 3-50 \cdot 0$ & 13.9 & $4.8-31.5$ & $16 \cdot 2$ & $7 \cdot 4-27 \cdot 3$ & 3.9 & $0.0-10.2$ & 0.8 & $0.0-1 \cdot 0$ & 25.0 & $12 \cdot 3-37.5$ \\
\hline & & & \multirow{2}{*}{\multicolumn{2}{|c|}{$\begin{array}{l}6.0 \\
0.12\end{array}$}} & \multirow{2}{*}{\multicolumn{2}{|c|}{$\begin{array}{l}1.4 \\
0.57\end{array}$}} & \multirow{2}{*}{\multicolumn{2}{|c|}{$\begin{array}{l}0.04 \\
0.82\end{array}$}} & \multirow{2}{*}{\multicolumn{2}{|c|}{$\begin{array}{l}9.8 \\
0.08\end{array}$}} & \multirow{2}{*}{\multicolumn{2}{|c|}{$\begin{array}{l}0.5 \\
0.90\end{array}$}} & \multirow{2}{*}{\multicolumn{2}{|c|}{$\begin{array}{c}0.2 \\
0.97\end{array}$}} & \multirow{2}{*}{\multicolumn{2}{|c|}{$\begin{array}{l}0.5 \\
0.67\end{array}$}} & \multirow{3}{*}{\multicolumn{2}{|c|}{$\begin{array}{l}-0.2 \\
0.20\end{array}$}} & \multirow{2}{*}{\multicolumn{2}{|c|}{$\begin{array}{l}1.3 \\
0.67\end{array}$}} \\
\hline $\begin{array}{l}\beta^{*}, \dagger \\
P^{*}, \dagger\end{array}$ & & $\begin{array}{l}0.4 \\
0.93\end{array}$ & & & & & & & & & & & & & & & & & & \\
\hline \multicolumn{3}{|c|}{ Sami $v$. non-Sami (ref.) } & \multirow{2}{*}{\multicolumn{2}{|c|}{$\begin{array}{r}3.9 \\
0.13\end{array}$}} & \multirow{2}{*}{\multicolumn{2}{|c|}{$\begin{array}{l}1.6 \\
0.26\end{array}$}} & \multirow{2}{*}{\multicolumn{2}{|c|}{$\begin{array}{l}0.04 \\
0.67\end{array}$}} & \multirow{2}{*}{\multicolumn{2}{|c|}{$\begin{array}{c}15.2 \\
<0.0001\end{array}$}} & \multirow{3}{*}{\multicolumn{2}{|c|}{$\begin{array}{l}-2.8 \\
0.41\end{array}$}} & \multirow{3}{*}{\multicolumn{2}{|c|}{$\begin{array}{l}-4 \cdot 6 \\
0.26\end{array}$}} & \multirow{3}{*}{\multicolumn{2}{|c|}{$\begin{array}{c}1.9 \\
0.05\end{array}$}} & & & & \\
\hline $\begin{array}{l}\beta^{*}, \dagger \\
P^{*}, \dagger\end{array}$ & & $\begin{array}{l}-9.2 \\
0.01\end{array}$ & & & & & & & & & & & & & & & & $\begin{array}{l}\times 10^{-16} \\
1.0\end{array}$ & & $\begin{array}{l}16.8 \\
0.0001\end{array}$ \\
\hline $\begin{array}{l}\text { Coastal region } \\
\text { Non-Sami }\end{array}$ & 41.9 & $20.5-$ & 23.3 & & & & & & & & & & & & & & & & & \\
\hline $\begin{array}{l}\text { Non-Sami } \\
\text { Multi-ethnic } \\
\text { Sami }\end{array}$ & $\begin{array}{l}41.9 \\
42 \cdot 8\end{array}$ & $\begin{array}{l}20 \cdot 5-70 \cdot 1 \\
23 \cdot 6-70 \cdot 1\end{array}$ & $\begin{array}{l}23.3 \\
24.6\end{array}$ & $\begin{array}{l}11.5-36 \cdot 6 \\
16 \cdot 0-41 \cdot 3\end{array}$ & $\begin{array}{l}0.0 \\
1.5\end{array}$ & $\begin{array}{l}0.0-4 \cdot 0 \\
0.0-6 \cdot 3\end{array}$ & $\begin{array}{l}1.0 \\
1.0\end{array}$ & $\begin{array}{l}0.8-2.4 \\
0.9-2.8\end{array}$ & $\begin{array}{l}3.5 \\
5.3\end{array}$ & $\begin{array}{l}0.0-7.0 \\
3 \cdot 5-12 \cdot 3\end{array}$ & $\begin{array}{l}32.0 \\
31.5\end{array}$ & $\begin{array}{l}15 \cdot 8-5 \cdot 3 \\
15 \cdot 8-49 \cdot 6\end{array}$ & $\begin{array}{l}20.1 \\
22.2\end{array}$ & $\begin{array}{r}9.3-32.9 \\
13 \cdot 9-36.5\end{array}$ & $\begin{array}{l}0.0 \\
0.0\end{array}$ & $\begin{array}{l}0.0-1.9 \\
0.0-4.0\end{array}$ & $\begin{array}{l}0.9 \\
0.9\end{array}$ & $\begin{array}{l}0.6-1 \cdot 7 \\
0.7-2 \cdot 1\end{array}$ & $\begin{array}{l}1.8 \\
5.3\end{array}$ & $\begin{array}{l}0.0-5 \cdot 3 \\
1.8-8 \cdot 2\end{array}$ \\
\hline Sami & 31.5 & $15 \cdot 2-60 \cdot 6$ & 26.6 & $17 \cdot 4-40.5$ & 3.9 & $0.0-11.8$ & 1.0 & $0.8-2 \cdot 4$ & $7 \cdot 0$ & $3.5-16.4$ & $30 \cdot 3$ & $13 \cdot 0-53 \cdot 5$ & 20.4 & $11.5-35.7$ & 1.1 & $0 \cdot 0-6 \cdot 0$ & 0.9 & $0.7-2.0$ & 8.2 & $3.5-12.5$ \\
\hline $\begin{array}{c}\text { Multi-ethnic } S \\
\beta^{\star}, \dagger \\
P^{\star}, \dagger\end{array}$ & ami $v$. non- & $\begin{array}{l}\text { 7-Sami (ref.) } \\
1.7 \\
0.63\end{array}$ & & $\begin{array}{c}2.4 \\
0.07\end{array}$ & & $\begin{array}{c}1.5 \\
0.004\end{array}$ & & $\begin{array}{c}0.1 \\
0.22\end{array}$ & & $\begin{array}{l}3.0 \\
0.0001\end{array}$ & & $\begin{array}{l}-2.4 \\
0.23\end{array}$ & & $\begin{array}{c}1.4 \\
0.39\end{array}$ & -2 & $\begin{array}{l}3 \times 10^{-16} \\
1.0\end{array}$ & & $\begin{array}{c}0.1 \\
0.12\end{array}$ & & $\begin{array}{l}3.5 \\
0.0001\end{array}$ \\
\hline $\begin{array}{c}\text { Sami v. non- } \\
\beta^{\star}, \dagger \\
P^{\star}, \dagger\end{array}$ & $\begin{array}{r}\text { ami (ref.) } \\
\quad<0 \\
<0\end{array}$ & $\begin{array}{l}-12.3 \\
0.0001\end{array}$ & & $\begin{array}{c}4.8 \\
0.02\end{array}$ & & $\begin{array}{l}3.9 \\
+0.0001\end{array}$ & & $\begin{array}{c}0.1 \\
0.44\end{array}$ & & $\begin{array}{l}4.7 \\
0.0001\end{array}$ & & $\begin{array}{l}-6.2 \\
0.03\end{array}$ & & $\begin{array}{c}1.3 \\
0.42\end{array}$ & & $\begin{array}{c}1.1 \\
0.09\end{array}$ & & $\begin{array}{l}0.02 \\
0.57\end{array}$ & & $\begin{array}{l}5.3 \\
0.0001\end{array}$ \\
\hline
\end{tabular}

$P 25,25$ th percentile; $P 75,75$ th percentile; ref., reference category.

${ }^{\star} \beta$ and $P$ value from quantile regression (at the median), adjusted for age $\left(40-49,50-59,60-69\right.$ years), education $\left(<13, \geq 13\right.$ years), physical activity level (three groups), BMl ( $\left.<30, \geq 30 \mathrm{~kg} / \mathrm{m}^{2}\right)$, smoking status (current, former, never) and energy intake (tertiles; $\mathrm{MJ}$ ).

tIn bold font if statistically significant in the fully adjusted model. 
to prevalence of dietary-related chronic diseases in the Sami population need to be investigated in more detail to explain the observed heterogeneity across sexes and geographical regions in this population.

\section{Limitations}

We detected lower EI in males with Sami ethnicity than in males with non-Sami and multi-ethnic Sami ethnicity. In females, the highest EI was observed in multi-ethnic Sami. A limitation of the present study was that the questionnaire has not been specifically validated in males or in the Sami population. Thus, it is possible that the EI in Sami males was underestimated, because the FFQ may not be wellsuited for Sami males. A more detailed FFQ in terms of traditional Sami foods and dishes may be needed to better estimate the current food intake in Sami people. For instance, the traditional Sami diet may contain dried reindeer meat that is not necessarily consumed at regular meals but eaten in between meals. There are many different combinations of a traditional, reindeer-based Sami meal. Indeed, in addition to meat, meals may consist of reindeer liver, bone marrow, tongue, tallow and other reindeer parts. Traditional Sami cuisine includes reindeer broth and soup/stew. New recipes, which are a combination of the old traditional diet and the modern diet, are emerging. However, it was not feasible to include related questions, as it would have resulted in an FFQ that was too long and detailed for the present, large population-based study. Thus, adjustments were made to the NOWAC FFQ, mainly through the addition of some known traditional Sami food items, including freshwater fish, reindeer meat, moose meat and food made with animal blood. These food items are most often consumed by the Sami population and contributed considerably to nutrient intakes.

The identification of ethnicity in multi-ethnic population-based studies is challenging ${ }^{(41)}$. A harsh assimilation policy made many Sami abandon their culture and language, and in certain regions, people of Sami origin are likely to say that they regard themselves as Norwegian instead of Sami. There are no standardized and validated methods to determine ethnicity, but there are two main approaches. The first one includes objective measures, based on ancestry or a connection to Sami language, and the second one is based on self-perception. Selfperception as a determinant of ethnicity is widely used in international research ${ }^{(42)}$ and was used in the current project. We hypothesized that self-perceived ethnicity may be strongly associated with cultural practices like dietary habits. Therefore, our results may not be applicable to Sami populations whose ethnicity is determined using a different approach.

One more limitation can be attributed to the reduced generalizability and external validity of the results because the response rate was only $47 \%$, the study sample was limited to individuals aged 40-69 years and only ten municipalities were included. The response rate among 
younger males in the SAMINOR 2 Clinical Survey was lower. In addition, the response rate among some categories of participants, namely individuals with fewer health concerns and lower education level, may be lower.

Self-reported data on dietary intake and lifestyle factors are known to be subject to recall biases in populationbased studies. We do not have information on the tendency to report healthier lifestyle among the solely Sami, multi-ethnic Sami and non-Sami ethnic groups, and it might be interesting to develop this knowledge.

\section{Strengths}

The present study is a follow-up of the SAMINOR 1 Survey, which included only a limited number of dietary questions. The SAMINOR 2 Clinical Survey questionnaire is much more comprehensive and gives a better assessment of total diet. Other strengths of the present study include its large sample size, detailed information on selfperceived ethnicity, and recruitment of participants from a large geographical area that covered both the inland and coastal regions of northern Norway. We adjusted for important covariates related to food intake that were different between the ethnic groups studied.

\section{Conclusion}

Food intake in rural areas of northern Norway is related to ethnicity and geographical region. Individuals with solely self-perceived Sami ethnicity differ more from non-Sami participants than participants with a self-perceived multiethnic Sami ethnicity, especially with respect to the intake of reindeer meat in the inland region. Our results contribute to the knowledge on current food intake in the rural population of northern Norway according to selfperceived ethnicity.

\section{Acknowledgements}

Acknowledgements: The authors gratefully acknowledge the participants and staff of the SAMINOR 2 Clinical Survey, and the Centre for Sami Health Research, UiT The Arctic University of Norway, for access to the data. Financial support: The SAMINOR 2 Clinical Survey was financed by the Norwegian Ministry of Health and Care Services; the Northern Norway Regional Health Authority; the Regional Research Fund of Northern Norway; the Sami Parliament; the Sami Norwegian National Advisory Unit on Mental Health and Substance Use; and the Finnmark, Troms and Nordland County Councils. The present postdoctoral research project was financially supported by the Department of Community Medicine, UiT The Arctic University of Norway. The funders had no role in the design, analysis or writing of this study. Conflict of interest: The authors declare that they have no conflict of interest. Authorship: N.P. analysed the data and wrote the manuscript.
G.S. calculated food intake and revised the paper. M.M. was responsible for the database, helped with statistical analyses, designed the map of the study and revised the paper. M.B. designed the study and revised the paper. All authors approved the final version of manuscript. Ethics of buman subject participation: The Regional Committee for Medical and Health Research Ethics of Northern Norway (REK-Nord) approved the SAMINOR 2 Clinical Survey. The storing of personal data for the SAMINOR 2 Clinical Survey was approved by the National Data Inspectorate. The application for this research project was approved by the Regional Committee for Medical and Health Research Ethics of Northern Norway (REK-Nord). All participants signed an informed consent form.

\section{Supplementary material}

To view supplementary material for this article, please visit https://doi.org/10.1017/S1368980018001374

\section{References}

1. Kuhnlein HV, Chan HM, Leggee D et al. (2002) Macronutrient, mineral and fatty acid composition of Canadian arctic traditional food. I Food Compost Anal 15, 545-566.

2. Hassan AA, Sandanger TM \& Brustad M (2012) Selected vitamins and essential elements in meat from semidomesticated reindeer (Rangifer tarandus tarandus L.) in mid- and northern Norway: geographical variations and effect of animal population density. Nutrients 4, 724-739.

3. Kuhnlein H, Erasmus B, Creed-Kanashiro H et al. (2006) Indigenous peoples' food systems for health: finding interventions that work. Public Health Nutr 9, 1013-1019.

4. Kuhnlein HV (2015) Food system sustainability for health and well-being of Indigenous Peoples. Public Health Nutr 18, 2415-2424.

5. McLaughlin JB, Middaugh JP, Utermohle CJ et al. (2004) Changing patterns of risk factors and mortality for coronary heart disease among Alaska Natives, 1979-2002. JAMA 291, $2545-2546$.

6. Friborg JT \& Melbye M (2008) Cancer patterns in Inuit populations. Lancet Oncol 9, 892-900.

7. Jernigan VB, Duran B, Ahn D et al. (2010) Changing patterns in health behaviors and risk factors related to cardiovascular disease among American Indians and Alaska Natives. Am J Public Health 100, 677-683.

8. Kuhnlein HV, Receveur O, Soueida R et al. (2004) Arctic indigenous peoples experience the nutrition transition with changing dietary patterns and obesity. J Nutr 134, 1447-1453.

9. International Labour Office (2003) ILO Convention on Indigenous and Tribal Peoples (1989) (No. 169): A Manual. http://www.ilo.org/wcmsp5/groups/public/@ed_norm/@nor mes/documents/instructionalmaterial/wcms_088485.pdf (accessed February 2016).

10. Aubert V (1978) Den samiske befolkningen $i$ Nord-Norge. vol. 107: Sámi ál'bmut Davvi-Norgas (The Lappish Population in Northern Norway. vol. 107: Sámi ál'bmut DavviNorgas). Oslo: Statistisk sentralbyrå.

11. Solbakk JT \& Biti BH (2006) Samene: en handbook (The Sámi People: A Handbook). Karasjok: Davvi Girji AS.

12. Solvang A \& Øgrim ME (1967) Kostholdsundersøkelser $i$ Kautokeino og Karasjok (Dietary Surveys in Kautokeino 
and Karasjok). Oslo: Landsforeningen for kosthold og helse.

13. Bardølsgaard K \& Øgrim ME (1963) Kostholdsundersøkelser i Havøysund (Dietary Surveys in Havøysund). Oslo: Landsforeningen for kosthold og helse.

14. Solvang A \& Øgrim ME (1963) Kostholdsundersøkelser $i$ Gamvik herred (Dietary Surveys in Gamvik). Oslo: Landsforeningen for kosthold og helse.

15. Sørum HM \& Øgrim ME (1962) Kostholdsundersøkelser $i$ Polmak (Dietary Surveys in Polmak). Oslo: Landsforeningen for kosthold og helse.

16. Nystad T, Melhus M, Brustad M et al. (2010) The effect of coffee consumption on serum total cholesterol in the Sami and Norwegian populations. Public Health Nutr 13, 1818-1825.

17. Nilsen H, Utsi E \& Bønaa KH (1999) Dietary and nutrient intake of a Sami population living in traditional reindeer herding areas in north Norway: comparisons with a group of Norwegians. Int J Circumpolar Health 58, 120-133.

18. Thørring H, Hosseini A \& Skuterud L (2004) Kostholdsundersøkelser 1999 og 2002: reindriftsutøvere i Kautokeino (Dietary Surveys in 1999 and 2002: Reindeer Herders in Kautokeino). Østerås: Statens strålevern.

19. Broderstad AR, Melhus M, Brustad M et al. (2011) Iron stores in relation to dietary patterns in a multiethnic population: the SAMINOR study. Public Health Nutr 14, 1039-1046.

20. Brustad M, Parr CL, Melhus M et al. (2008) Dietary patterns in the population living in the Sami core areas of Norway the SAMINOR study. Int J Circumpolar Health 67, 82-96.

21. Brustad M, Parr CL, Melhus M et al. (2008) Childhood diet in relation to Sami and Norwegian ethnicity in northern and mid-Norway - the SAMINOR study. Public Health Nutr 11, $168-175$.

22. Nilsson LM, Dahlgren L, Johansson I et al. (2011) Diet and lifestyle of the Sami of southern Lapland in the 1930s-1950s and today. Int J Circumpolar Health 70, 301-318.

23. Nilsson LM, Winkvist A, Brustad M et al. (2012) A traditional Sami diet score as a determinant of mortality in a general northern Swedish population. Int J Circumpolar Health $\mathbf{7 1}$, $1-12$.

24. Nilsson LM, Winkvist A, Eliasson M et al. (2012) Low-carbohydrate, high-protein score and mortality in a northern Swedish population-based cohort. Eur J Clin Nutr 66, 694700 .

25. Nilsson LM, Johansson I, Lenner P et al. (2010) Consumption of filtered and boiled coffee and the risk of incident cancer: a prospective cohort study. Cancer Causes Control 21, 1533-1544.

26. Nilsson LM, Wennberg M, Lindahl B et al. (2010) Consumption of filtered and boiled coffee and the risk of first acute myocardial infarction; a nested case/referent study. Nutr Metab Cardiovasc Dis 20, 527-535.

27. World Health Organization (1985) Energy and Protein Requirements. Report of a Joint FAO/WHO/UNU Expert Consultation. WHO Technical Report Series no. 724. Geneva: WHO.
28. Lund E, Melhus M, Hansen KL et al. (2007) Population based study of health and living conditions in areas with both Sami and Norwegian populations - the SAMINOR study. Int J Circumpolar Health 66, 113-128.

29. Parr CL, Veierød MB, Laake P et al. (2006) Test-retest reproducibility of a food frequency questionnaire (FFQ) and estimated effects on disease risk in the Norwegian Women and Cancer Study (NOWAC). Nutr J 5, 4.

30. Hjartåker A, Lund E \& Bjerve KS (1997) Serum phospholipid fatty acid composition and habitual intake of marine foods registered by a semi-quantitative food frequency questionnaire. Eur J Clin Nutr 51, 736-742.

31. Hjartåker A, Andersen LF \& Lund E (2007) Comparison of diet measures from a food-frequency questionnaire with measures from repeated 24-hour dietary recalls. The Norwegian Women and Cancer Study. Public Health Nutr 10, 1094-1103.

32. Davino C, Furno M \& Vistocco D (2014) Quantile Regression. Oxford: John Wiley \& Sons Ltd.

33. Brox J, Bjørnstad E \& Olaussen K (2003) Hemoglobin, iron, nutrition and life-style among adolescents in a coastal and an inland community in northern Norway. Int J Circumpolar Health 62, 130-141.

34. Andersen S, Rex KF, Noahsen P et al. (2014) Forty-five year trends in overweight and obesity in an indigenous arctic Inuit society in transition and spatiotemporal trends. $A m \mathrm{~J}$ Hum Biol 26, 511-517.

35. Nystad T, Melhus M, Brustad M et al. (2010) Ethnic differences in the prevalence of general and central obesity among the Sami and Norwegian populations: the SAMINOR study. Scand J Public Health 38, 17-24.

36. Broderstad AR \& Melhus M (2016) Prevalence of metabolic syndrome and diabetes mellitus in Sami and Norwegian populations. The SAMINOR - a cross-sectional study. BMJ Open 6, e009474.

37. Niølstad I, Arnesen E \& Lund-Larsen PG (1998) Cardiovascular diseases and diabetes mellitus in different ethnic groups: the Finnmark study. Epidemiology 9, 550-556.

38. Naseribafrouei A, Eliassen BM, Melhus M et al. (2016) Ethnic difference in the prevalence of pre-diabetes and diabetes mellitus in regions with Sami and non-Sami populations in Norway - the SAMINOR1 study. Int J Circumpolar Health 75, 31697 .

39. Johnson-Down L, Labonte ME, Martin ID et al. (2015) Quality of diet is associated with insulin resistance in the Cree (Eeyouch) indigenous population of northern Quebec. Nutr Metab Cardiovasc Dis 25, 85-92.

40. Ryman TK, Boyer BB, Hopkins S et al. (2015) Associations between diet and cardiometabolic risk among Yup'ik Alaska Native people using food frequency questionnaire dietary patterns. Nutr Metab Cardiovasc Dis 25, 1140-1145.

41. Siri SRA (2015) Use of Sami Ethnicity in Health Research and Registries. Tromsø: Centre for Sami Health Research, UiT The Arctic University of Norway.

42. Pettersen T (2015) Sami ethnicity as a variable. PhD Thesis, UiT The Arctic University of Norway. 